\title{
NEXUS BETWEEN ECONOMIC FREEDOM AND ECONOMIC GROWTH: AN EMPIRICAL STUDY OF UAE THROUGH BOUNDS TESTING APPROACH
}

\section{DR. RUBY KHAN \& DR. KAVITA PANJWANI}

Assist. Professor, Dept. of Finance and Banking, College of Business Administration, Jazan University, Jazan, KSA

ABSTRACT
This research used co integration bounds tests based on annual time series data from 1996 to 2020 to examine the long-
term and short-term effects of different determinants of the GDP economic freedom index on GDP Per Capita PPP \$ in
United Arab Emirates (UAE). Three determinants out of eight are found as significant regressors, based on descriptive
statistics, and therefore focused on the study. These are Financial Freedom (FinF), Freedom from corruption (FFC)
and Trade Freedom (TF). This study also recommends to enhance the leftover determinants of economic freedom to
boost the country's economic growth.
KEYWORDS: Gross Domestic Product, Per Capita Income, Economic Freedom, Financial Freedom, Freedom From
Corruption, Trade Freedom, Co Integration, Auto Regression

Received: Feb 15, 2021; Accepted: Mar 05, 2021; Published: Mar 22, 2021; Paper Id.: IJBMRAPR20211

\section{INTRODUCTION}

Influential economies today are not inherently broad in geography or richly endowed with natural resources. By improving their economic dynamism, many economies are putting efforts to increase opportunities for their people. The overarching goal of economic policies is to create and develop an atmosphere that helps transform opportunity into prosperity. The most productive stimulus operation of a government would not be to increase its spending or increase regulatory layers, limiting economic independence. Instead, the best outcomes can be achieved through policy changes that strengthen entrepreneurship conditions, creating more prospects for greater economic dynamism.

Unprecedented economic development has been fueled by the free-market economy embedded in the ideals of economic freedom: individual empowerment, non-discrimination, and fair competition. The necessity for dynamic economic growth and genuine change, no matter the current degree of development of a nation, is to advance economic independence. There is a robust association between increased labor independence and per capita rate of economic growth. Improvements in economic freedom are a vital element in reaching economic growth rates that are high enough to eliminate poverty significantly. Countries that step towards greater economic independence prefer to experience higher per capita GDP growth rates.

\section{Economic Freedom in United Arab Emirates}

Seven monarchies in UAE consist of Abu Dhabi, Ajman, Dubai, Fujairah, Ras Al-Khaimah, Sharjah, and Umm alQaiwain. It is considered an open economy with a high per capita income and a significant annual trade surplus. In 60 years since oil was discovered in UAE, the world has experienced a remarkable change from a poor and backward region to a rich and advanced country. 
Government has increased spending on infrastructure and job growth. It opens infrastructure for greater privatesector competition. World free trade zones help draw international investors due to reduced taxes and zero limits on ownership. In the next five years, the UAE's strategic plan will focus on diversifying the economy, producing a global hub for tourism and trade, and creating more employment opportunities in the private sector. The United Arab Emirates ranked 76.2 in economic freedom, making its economy the 18th-highest in the 2020 Index. In the Middle East and North Africa region, the United Arab Emirates has ranked 1st out of 14 nations and their overall performance far exceeds regional and global averages. Since 2013, United Arab Emirates' economies have increasingly risen to a mostly open rank. (Country Rankings, 2020)

\section{LITERATURE REVIEW}

Many researchers believe that economic rights (mainly land and contracts) help promote economic growth, but this relationship is barely empirically studied. Arthur A. Goldsmith discussed this topic taking three economic freedom indices. It finds that developing nations often appear to progress, grow faster, and rank higher in human development if they score well in securing economic rights. (Goldsmith, 1997)

A study done by Elham Beheshtitabar and Asset Irgaliyev explores how FDI inflows are affected by economic freedom in developed nations and particularly in the Middle East. Four factors, namely Freedom from corruption, Government Size, Freedom of Trades, and Freedom of Investment, were tested as variables for evaluating FDI inflow. Cross-sectional data were collected between 1995 and 2006 for twelve Middle Eastern states and forty-three other developing countries. It has been found that in both Middle East and other countries only trade freedom and investment freedom were relevant. Based on their results, they proposed strengthening the investment climate and reducing trade barriers to bring more FDI. (Beheshtitabar \& Irgaliyev, 2008)

Investment risk is a multi-faceted component, representing many issues important to (foreign) investors, such as accountability, corruption, the legal system, leadership, etc. A study of José Caetano and Antonio Caleiro explores the degree of economic freedom and analyzes how these risk measures with foreign direct investment results. The paper uses Fuzzy logic clustering to check that MENA countries are distinct from various European Union countries. The results prove a good relationship between a country's economic freedom and inward FDI from unique economic concerns the inclusion of some Middle Eastern countries in the same cluster as other European Union countries. (Caetano \& Caleiro, 2009)

The paper by Muawya Ahmed Hussein examines and analyzes details related to FDI foreign direct investment in six countries (United Arab Emirates and the Kingdom of Saudi Arabia, Oman, Qatar, Kuwait, Bahrain) establishing the Arab States Gulf Cooperation Council. It is checked to what degree these countries have acknowledged the significance of FDI in the development phase and what steps have been taken to draw foreign capital and promote foreign investment. GCC countries have taken several steps to create an enticing investment climate. These include lowering corporate income tax rates, including tax holidays, speeding up visa issuing, creating a one-stop-shop that minimizes investment acceptance and recording time, selling opportunities for available investment, and removing or reducing minimum capital requirements. The GCC countries have empirically employed theories of growth and statistical techniques in recent years to examine the relationship between FDI and economic growth. (Hussein, 2009)

Kamal Smimou and Amela Karabegovic have researched the relationship between economic freedom and equity 
returns. The relationship between the Economic Freedom Index and equity returns is evaluated in this research paper to fill a gap in the previous study of stock markets that excluded the Middle East and North Africa (MENA). Evidence has shown that improvements in economic freedom have a positive effect on stock market sales, which are regarded as non-business cycle control variables in terms of anticipated returns, and that the legal framework and regulation of property rights have the most important consequences for equity market returns. (Smimou \& Karabegovic, 2010)

The journal article by Najeb Masoud and Glenn Hardaker offers a theoretical framework that incorporates the theory of endogenous growth and the functioning of capital markets and institutions to examine how indicators influencing economic growth in any country are produced by the financial market and the banking sector. (Masoud \& Hardaker, 2012)

Muslim nations are typically not free and have a weak record of property rights, according to François Facchini. In the twentieth century, colonialism radically changed institutional life. British colonization was better than colonization by the French or Soviet. This clarifies why the nations of the Persian Gulf are freer. The Soviet model breakdown defines the pace of economic liberalization in former socialist countries (such as Albania, Kyrgyz Republic, and Kazakhstan. The paper, published in 2011, concludes that the past of the 20th century does not justify how the ideal of a Muslim city is drawn to Muslim countries. This research is sustained by the revival of Islamic intellectual advances and Muslim opinion.(Facchini, 2013)

Laura Asandului, Andreea Iacobuta, and Cristina Cautisanu plan to model the European Union Member States' economic growth regarding the economic freedom index and the economic progress index. A regression analysis was developed to examine the relationship between Economic Freedom Index and Social Development Index and the change in the per capita GDP growth rate in Europe. (Laura Asandului1, Andreea Iacobuta2, Cristina Cautisanu3, 2015)

In a study by Mohammed Ershad Hussain and Mahfuzul Haque, a composite index derived from several subindices discusses several unorthodox determinants of economic growth with the help of an index of economic freedom. The analysis contains two data-sets-based facts. Over 2013, 2014, and 2015, the first collection consists of 186 countries showing that structural variables playing a pivotal role in sustainable growth. For the period 2004-2014, a second data collection, with data for 57 countries, also indicates a positive effect on GDP growth rate per capita. (Hussain \& Haque, 2016)

A study by Tariq Bin Faisal Al Qassemi, Ahmed FikriMabrouk and Lamia Soliman Abdelghany explain how the government can ensure sustainable economic development when economic freedom policies are well institutionalized resulting in low-volatility equity capital and thus low-cost equity funding. This research explores the quantitative and empirical relationships between the Economic Freedom Index components of MENA countries (which are treated in this study as a proxy for institutional continuity) and volatility in stock exchanges. The results suggest that stock market volatility can be mitigated and decreased as strict enforcement, and successful regulation are related to economic freedom. However, high independence from corruption results in increased volatility associated with competitive stock trading, resulting in increased costs of equity financing. (Eldomiaty et al., 2016)

Jani Kinnunen's conference paper tries to measure relationships within the Islamic community. The 26 variables in total are used through clustering research to group the countries. The data is then positioned under a two-stage statistical analysis: firstly, the most essential variables are built by principal component analysis, which is, secondly, expanded by multiple correspondence analysis, MCA. PCA is conducted with all quantitative variables for the whole dataset and for 
each cluster individually, while MCA considers the entire set of countries and categorical groups of variables. Distinctive characteristics tend to be found in Islamic countries, although other findings are found quite same, conducted in related research on other countries.(Kinnunen, 2018)

The study by Hatem Hatef Abdulkadim Altaee and Mohamed Khaled Al-Jafari explores the effect of trade openness on economic growth in the Gulf Cooperation Council (GCC) countries, and economic growth stems from the relationship between gross fixed capital accumulation, energy use, imports and exports indicators. In part, it was shown that exports had a significant positive effect on economic growth, while imports had a substantial, if negative, impact on economic growth.(Altaee \& Al-Jafari, 2018)

In a journal article written by Mohamed Ben Mimoun and Ali Essaggay, the contribution of economic freedom is empirically calculated by the observed difference between GCC countries and East Asian NIEs in GDP per worker. The Fraser Institute and Heritage Foundation show that lower economic freedom in the GCC region over the last five decades is a major cause of its low competitiveness compared to East Asian countries. Total Factors productivity transmits the entirety of this effect. The obtained findings rely on GCC governments to further free their economic institutions. (Mimoun \& Essaggay, 2018)

Anwar Al-Gasaymeh investigates the impact on bank costs of the next Gulf Cooperation Council (GCC) union of economic freedom and national challenges. In his paper, he uses the Stochastic Frontier Approach (SFA) to monitor country-specific variables, i.e., economic independence, country risk, macro-economic factors, banking functionality, and banking structure, for an unbalanced panel of 90 banks from Jordan and GCC countries. This article further predicts that the efficiency levels of banks will be eliminated in the prospective GCC Member States. Economic independence has been shown to be effective in reducing future banking costs. Improving economic freedom is essential for the country to attract more investment and grow a sustainable banking sector. (Al-Gasaymeh, 2020)

This article presents a systematic empirical study and analyzes the effects of economic freedom and its various drivers on economic growth and per capita potential of the United Arab Emirates. Considering specific historical facts and studies, along with World Bank statistics, this quantitative data analysis will try to contemplate specific results of the investigation.

\section{Data and Methodological Issues}

The study is based on the secondary data source consisting of the United Arab Economic annual findings from 1996 to 2020. In order to examine the relation between the economic freedom of the UAE and its economic well-being, we have taken Gross Domestic Product per capita income (GDP per capita PPP \$) as a dependent variable. The required data on various indicators is taken from authentic sources of published World Bank Statistics.(United Arab Emirates Economic Freedom, Overall Index - Data, Chart, n.d.)

\section{Description of Variables}

Dependent variable: GDP Per Capita purchasing power parity is our dependent variable, which is measured in U.S. dollars, and its source is published data of The World Bank.

Independent variable: Economic Freedom Index and its various determinants such as

Property rights (PR), freedom from corruption (FFC), and fiscal freedom (FF), Monetary freed (MF), Trade freedom (TF), 
Investment freedom (IF), Business freedom (BF) and Financial Freedom (FinF). Variable is measured in index points, and its source is published data of The Heritage Foundation.

\section{Time Series Econometric Analysis}

This study adopts various approaches to analyze the data.

\section{Step 1: Descriptive Analysis}

A detailed statistical analysis is carried out before the time series econometric analysis. We have 24 years of annual observations from 1996 to 2020 in our entire data collection (See Appendix I for data). Under this analysis, we will calculate Mean, Median, Mini-Max, Standard deviation, Skewness, Kurtosis, Jarque-Bera, Probability, etc.

\section{Step 2: Analysis of Regression $(y=\alpha+\beta x)$}

We will apply this analysis to determine which factors or variables matter most, which it can ignore and how these variables interact with each other. Here ' $y$ ' is dependent variable GDP Per Capita PPP \$ and ' $x$ ' are various Economic Freedom Index determinants.

\section{Step 3: Test of Stationarity}

The use of time-series data also includes the potential to obtain spurious regression. Therefore, the stationary testing of the variables in the model is essential. We will simultaneously convert the series to stationary using the appropriate difference.

\section{Step 4: Estimation Strategy}

In this study, Pesaran et al. used the Auto-Regressive Distributed Lag Bound Testing Technique (2001). ARDL has many advantages over other approaches of cointegration, such as Engle and Granger, Johansen and Juselius (1990).

- It can be implemented regardless of I(0), I(1), or I(2) are the underlying variables(Pesaran, 1997).

- To test the cointegration relationship in small samples with the cointegration techniques of Johansen and Juselius, the ARDL approach is statistically more important. (Pesaran et al., 1999).

- Even if some models are endogenous, the boundary test approach typically provides unbiased long-term estimates and exact t-statistics. (Narayan, 2005)

- The model takes a reasonable number of lags within unique modeling frameworks to capture the data generation process in general. (Laurenceson \& Chai, 2003)

- ARDL can be derived via a simple linear transformation from the error correction model (ECM), combining short-term and long-term equilibrium adaptations without losing long-term details. (Pesaran et al., 1999)

We adopted this methodology for our analysis due to numerous econometric advantages over other methods of cointegration, and define the following model as follows:

$\ln (\mathrm{GDP}$ Per Capita PPP $\$)=\beta 0+\beta 1(\mathrm{FFCt})+\beta 2(\mathrm{FinFt})+\beta 3(\mathrm{TFt})+\mathrm{Ut}$

Where natural log value of GDP per capita PPP \$ is the dependent variable and FFCt, FinFt and TFt represent Freedom from corruption, Financial Freedom, and trade freedom, respectively, are independent variables. Parameters $\beta 1$, $\beta 2$ and $\beta 3$ are the long-term elasticities of GDP per capita PPP\$ in terms of FFCt, FinFt and TFt, respectively. 
MS Excel and E-views econometric software is used to process and run various functions.

\section{RESULTS AND DISCUSSION}

\section{Descriptive Analysis}

Descriptive analysis in Table 1 exhibits averages and standard deviations of our dependent and independent variables. Few independent variables are negatively skewed, and few show positive skewness, whereas the dependent variable shows positive skewness. Kurtosis statistics shows that only Fiscal freedom (FF) and Financial freedom (FinF) are leptokurtic (long tail or higher). All other variables are platykurtic (short tailed or lower peak). When all other variables are normally distributed, the Jarque-Bera test reveals that Fiscal Freedom (FF) residuals are non-normally distributed.

Table 1

\begin{tabular}{|c|c|c|c|c|c|c|c|c|c|c|}
\hline \multicolumn{11}{|c|}{ Descriptive Statistics } \\
\hline & $\mathbf{B F}$ & FinF & $\mathbf{F F}$ & FFC & IF & MF & PR & TF & $\begin{array}{c}\text { Overall_- } \\
\text { EFI }\end{array}$ & $\begin{array}{l}\text { GDP Per } \\
\text { Capita }\end{array}$ \\
\hline Mean & 73.083 & 48.333 & 99.458 & 73.917 & 37.500 & 78.554 & 65.833 & 79.667 & 70.542 & 79272.790 \\
\hline Median & 74.500 & 50.000 & 100.000 & 70.000 & 35.000 & 79.250 & 62.500 & 78.500 & 72.000 & 72707.910 \\
\hline Maximum & 85.000 & 60.000 & 100.000 & 90.000 & 50.000 & 85.200 & 90.000 & 84.000 & 78.000 & 105109.000 \\
\hline Minimum & 48.000 & 30.000 & 95.000 & 52.000 & 30.000 & 68.800 & 40.000 & 75.000 & 62.000 & 54921.840 \\
\hline Std. Dev. & 12.126 & 8.681 & 1.318 & 13.015 & 7.802 & 4.464 & 18.222 & 3.306 & 4.672 & 18243.660 \\
\hline Skewness & -0.877 & -0.898 & -2.526 & 0.126 & 0.596 & -0.658 & 0.129 & 0.072 & -0.268 & 0.100 \\
\hline Kurtosis & 2.710 & 3.377 & 8.183 & 1.570 & 1.886 & 2.776 & 1.563 & 1.298 & 2.167 & 1.316 \\
\hline Jarque-Bera & 3.161 & 3.365 & 52.389 & 2.108 & 2.662 & 1.784 & 2.132 & 2.918 & 0.981 & 2.876 \\
\hline Probability & 0.206 & 0.186 & 0.000 & 0.349 & 0.264 & 0.410 & 0.344 & 0.232 & 0.612 & 0.237 \\
\hline Sum & 1754.000 & 1160.000 & 2387.000 & 1774.000 & 900.000 & 1885.300 & 1580.000 & 1912.000 & 1693.000 & 1902547.000 \\
\hline $\begin{array}{l}\text { Sum Sq. } \\
\text { Dev. }\end{array}$ & 3381.833 & 1733.333 & 39.958 & 3895.833 & 1400.000 & 458.300 & 7637.333 & 251.333 & 501.958 & $\begin{array}{c}7660000000 \\
000\end{array}$ \\
\hline
\end{tabular}

\section{Regression Analysis}

In Table 2, the standard error indicates how much variance there is from estimating the calculation of the slope coefficient. T-statistics calculates the number of standard errors that the coefficient is from zero. There is ample evidence against the null hypothesis that there is no correlation between dependent and independent variables in the case of Financial freedom (FinF), Freedom from corruption (FFC), and Trade freedom (TF) as t-statistics is above 2. For the same variables, the p-value (less than 0.05) indicates a higher degree of confidence in rejecting the null hypothesis. A very high value of R-square (97.89\%) and adjusted R-square (96.77\%) are also showing that the independent variables have high predictive power, and the model is good. F-statistic (87.177) and its p-value (0) indicate that the explanatory variables are essential in explaining the variable of the result. 
Table 2

\begin{tabular}{|c|c|c|c|c|}
\hline Variables & Co-efficient & Std. Error & t-Statistic & Prob. \\
\hline $\mathrm{C}$ & 404945.1 & 71735.8 & 5.644951 & 0 \\
\hline BUSINESS_FREEDOM (BF) & 299.132 & 150.1902 & 1.991689 & 0.0649 \\
\hline FINANCIAL_FREEDOM(FinF) & -755.6447 & 263.7575 & -2.864922 & 0.0118 \\
\hline FISCAL_FREEDOM (FF) & -1326.238 & 694.2021 & -1.910449 & 0.0754 \\
\hline $\begin{array}{l}\text { FREEDOM_FROM_CORRUPTION } \\
\text { (FFC) }\end{array}$ & 510.265 & 224.8659 & 2.269196 & 0.0384 \\
\hline INVESTMENT_FREEDOM(IF) & 146.0578 & 116.9167 & 1.249248 & 0.2307 \\
\hline MONETARY_FREEDOM (MF) & -193.197 & 219.3303 & -0.880849 & 0.3923 \\
\hline PROPERTY_RIGHTS (PR) & 192.0306 & 132.4076 & 1.450299 & 0.1676 \\
\hline TRADE_FREEDOM (TF) & -2758.563 & 602.1631 & -4.58109 & 0.0004 \\
\hline R-squared & 0.978945 & \multicolumn{2}{|l|}{ Mean dependent var } & 79272.79 \\
\hline Adjusted R-squared & 0.967716 & \multicolumn{2}{|l|}{ S.D. dependent var } & 18243.66 \\
\hline S.E. of regression & 3277.998 & \multicolumn{2}{|l|}{ Akaike info criterion } & 19.30785 \\
\hline Sum squared resid & $1.61 \mathrm{E}+08$ & \multicolumn{2}{|l|}{ Schwarz criterion } & 19.74962 \\
\hline Log likelihood & -222.6942 & \multicolumn{2}{|l|}{ Hannan-Quinn criter. } & 19.42505 \\
\hline F-statistic & 87.17711 & \multicolumn{2}{|l|}{ Durbin-Watson stat } & 2.490202 \\
\hline Prob(F-statistic) & 0 & & & \\
\hline \multicolumn{5}{|l|}{ Note: Calculated with E-View } \\
\hline \multicolumn{5}{|l|}{ Regression Analysis } \\
\hline \multicolumn{5}{|c|}{ *Dependent Variable: GDP Per Capita PPP \$ } \\
\hline \multicolumn{5}{|c|}{ ** Included observations: 24 after adjustments } \\
\hline
\end{tabular}

\section{EMPIRICAL FINDINGS}

\section{Unit Root Test Analysis}

Although ARDL cointegration method does not require unit root pre-tests, to avoid ARDL model crash within the context of the integrated stochastic framework of I (2), we feel that unit root test should be performed to identify the number of unit roots in the sequence under consideration. Table 3 suggests that at the first difference, all variables are stationary.

Table 3

\begin{tabular}{|l|c|c|c|c|}
\hline \multirow{2}{*}{\multicolumn{1}{c}{ Variables }} & \multicolumn{2}{c|}{$\begin{array}{c}\text { Augmented Dickey-Fuller Test } \\
\text { Statistic } \\
\text { (At Level) I(0) }\end{array}$} & \multicolumn{2}{c|}{$\begin{array}{c}\text { Augmented Dickey-Fuller Test } \\
\text { Statistic } \\
\text { (At First Difference) I(1) }\end{array}$} \\
\cline { 2 - 5 } & t-Statistic & Prob. & t-Statistic & Prob. \\
\hline GDP Per Capita PPP \$ & -1.470003 & 0.1288 & -2.444294 & 0.0171 \\
\hline Financial Freedom (FinF) & 0.150868 & 0.7208 & -4.690416 & 0.0001 \\
\hline Freedom From Corruption (FFC) & -0.989946 & 0.2796 & -3.554493 & 0.0011 \\
\hline Trade Freedom (TF) & 0.345246 & 0.7767 & -3.370443 & 0.0017 \\
\hline Results of Unit Root Test & \multicolumn{4}{|l}{} \\
\hline Ho: The variable has a unit root
\end{tabular}

Source: Authors' compilation from E-View results 
Hereafter our data series that is converted on I(1) will be used for further test implementation.

Autoregressive Distributed Lag Model (ARDL) Approach to Co-integration Testing or Bound Co-integration Testing Approach

\section{ARDL Results for Short Run}

Table 4

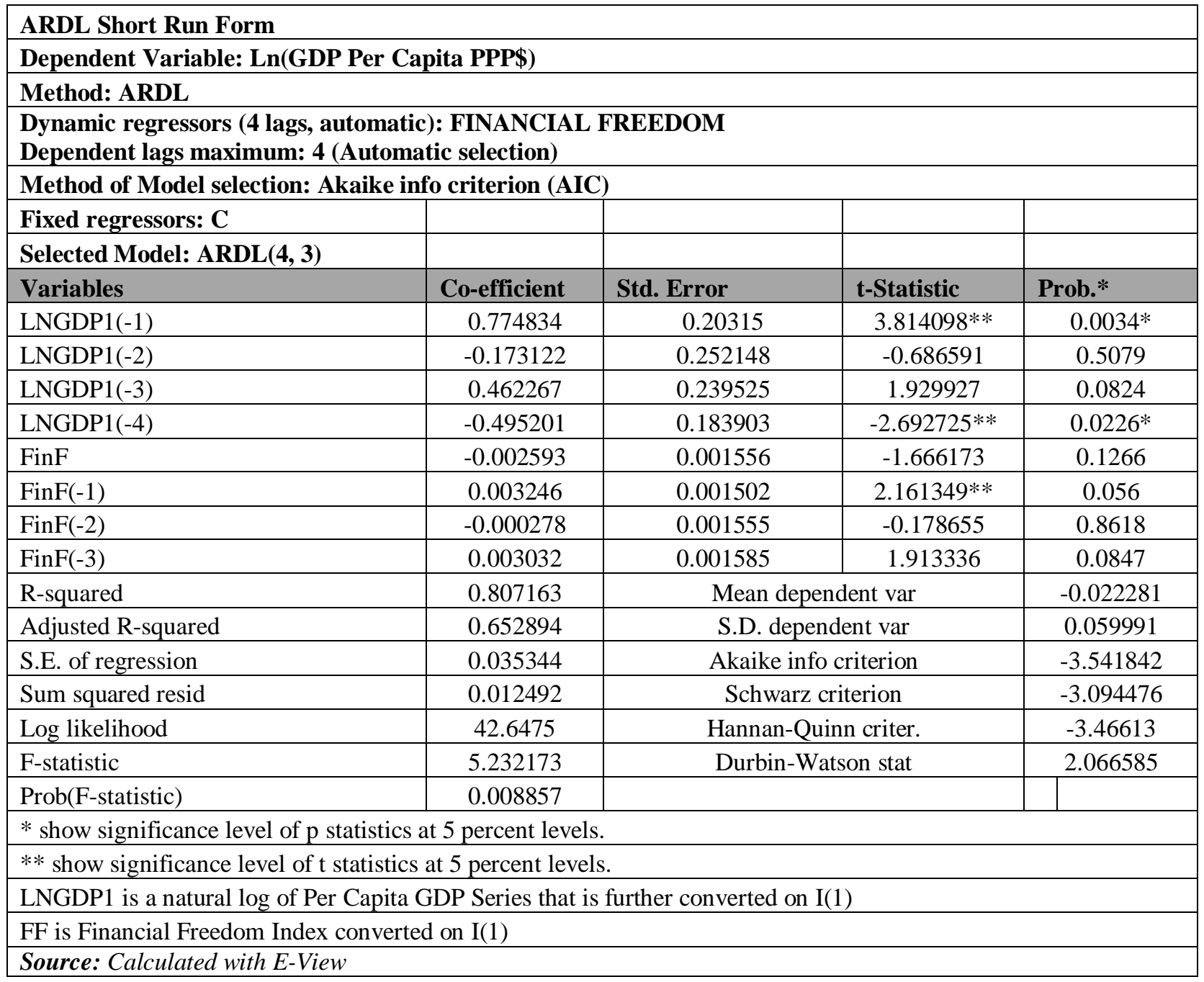

Table 5

\begin{tabular}{|c|c|c|c|c|}
\hline \multicolumn{5}{|c|}{ ARDL Short Run Form } \\
\hline \multicolumn{5}{|c|}{ Dependent Variable: Ln(GDP Per Capita PPP\$) } \\
\hline \multicolumn{5}{|c|}{$\begin{array}{l}\text { Method: ARDL } \\
\text { Dynamic regressors (4 lags, automatic): FREEDOM FROM CORRUPTION }\end{array}$} \\
\hline \multicolumn{5}{|c|}{ Dependent lags maximum: 4 (Automatic selection) } \\
\hline \multicolumn{5}{|c|}{ Method of Model selection: Akaike info criterion (AIC) } \\
\hline \multicolumn{5}{|c|}{ Fixed regressors: $\mathrm{C}$} \\
\hline \multicolumn{5}{|c|}{ Selected Model: ARDL $(1,4)$} \\
\hline Variable & Coefficient & Std. Error & t-Statistic & Prob.* \\
\hline LNGDP1(-1) & 0.486667 & 0.165364 & $2.943007 * *$ & $0.0123^{*}$ \\
\hline
\end{tabular}


Table 5: Contd.,

\begin{tabular}{|l|c|c|c|c|}
\hline FFC & 0.002423 & 0.001302 & 1.860627 & 0.0875 \\
\hline FFC(-1) & 0.000229 & 0.001371 & 0.166739 & 0.8704 \\
\hline FFC(-2) & 0.002442 & 0.001353 & 1.804891 & 0.0962 \\
\hline FFC(-3) & 0.000985 & 0.001355 & 0.726733 & 0.4813 \\
\hline FFC(-4) & 0.003477 & 0.001403 & $2.478109 * *$ & $0.0291 *$ \\
\hline C & -0.004113 & 0.008992 & -0.45734 & 0.6556 \\
\hline R-squared & 0.750615 & Mean dependent var & -0.022281 \\
\hline Adjusted R-squared & 0.625922 & S.D. dependent var & 0.059991 \\
\hline S.E. of regression & 0.036692 & Akaike info criterion & -3.495212 \\
\hline Sum squared resid & 0.016156 & Schwarz criterion & -3.147261 \\
\hline Log likelihood & 40.20451 & Hannan-Quinn criter. & -3.436325 \\
\hline F-statistic & 6.019718 & Durbin-Watson stat & 1.747807 \\
\hline Prob(F-statistic) & 0.00417 & & \\
\hline$*$ show significance level of p statistics at 5 percent levels. \\
\hline$* *$ show significance level of t statistics at 5 percent levels. \\
\hline LNGDP1 is a natural log of Per Capita GDP Series that is further converted on I(1) \\
\hline FFC is Freedom from Corruption Index converted on I(1) \\
\hline Source: Calculated with E-View \\
\hline
\end{tabular}

Table 6

\begin{tabular}{|c|c|c|c|c|}
\hline \multicolumn{5}{|c|}{ ARDL Short Run Form } \\
\hline \multicolumn{5}{|c|}{ Dependent Variable: Ln(GDP Per Capita PPP\$) } \\
\hline \multicolumn{5}{|c|}{$\begin{array}{l}\text { Method: ARDL } \\
\text { Dynamic regressors (4 lags, automatic): DTF }\end{array}$} \\
\hline \multicolumn{5}{|c|}{ Dependent lags maximum: 4 (Automatic selection) } \\
\hline \multicolumn{5}{|c|}{ Model selection method: Akaike info criterion (AIC) } \\
\hline \multicolumn{5}{|c|}{ Fixed regressors: $\mathrm{C}$} \\
\hline \multicolumn{5}{|c|}{ Selected Model: ARDL $(3,4)$} \\
\hline Variables & Coefficient & Std. Error & t-Statistic & Prob.* \\
\hline LNGDP1(-1) & 0.408364 & 0.203268 & $2.008996 * *$ & 0.0723 \\
\hline LNGDP1(-2) & 0.358656 & 0.204834 & 1.750959 & 0.1105 \\
\hline LNGDP1(-3) & 0.462534 & 0.211296 & $2.189032 * *$ & 0.0534 \\
\hline $\mathrm{TF}$ & 0.009726 & 0.006885 & 1.412767 & 0.1881 \\
\hline $\mathrm{TF}(-1)$ & 0.006886 & 0.006174 & 1.115372 & 0.2908 \\
\hline $\mathrm{TF}(-2)$ & 0.022303 & 0.006907 & $3.22914 * *$ & $0.009 *$ \\
\hline $\mathrm{TF}(-3)$ & 0.029064 & 0.006145 & $4.729331 * *$ & $0.0008^{*}$ \\
\hline $\mathrm{TF}(-4)$ & 0.014003 & 0.007177 & 1.951118 & 0.0796 \\
\hline $\mathrm{C}$ & -0.023871 & 0.008371 & $-2.85154 * *$ & $0.0172 *$ \\
\hline R-squared & 0.801455 & \multicolumn{2}{|c|}{ Mean dependent var } & -1861.882 \\
\hline Adjusted R-squared & 0.64262 & \multicolumn{2}{|c|}{ S.D. dependent var } & 4286.742 \\
\hline S.E. of regression & 2562.67 & \multicolumn{2}{|c|}{ Akaike info criterion } & 18.841 \\
\hline Sum squared resid & 65672769 & \multicolumn{2}{|c|}{ Schwarz criterion } & 19.28837 \\
\hline Log-likelihood & -169.9895 & \multicolumn{2}{|c|}{ Hannan-Quinn criteria. } & 18.91671 \\
\hline
\end{tabular}




\begin{tabular}{|c|c|c|c|}
\hline \multicolumn{4}{|c|}{ Table 6: Contd., } \\
\hline F-statistic & 5.045814 & Durbin-Watson stat & 2.58893 \\
\hline Prob(F-statistic) & 0.010077 & & \\
\hline \multicolumn{4}{|c|}{ * show significance level of p statistics at 5 percent levels. } \\
\hline \multicolumn{4}{|c|}{ ** show significance level of $\mathrm{t}$ statistics at 5 percent levels. } \\
\hline \multicolumn{4}{|c|}{ LNGDP1 is a natural log of Per Capita GDP Series that is further converted on I(1) } \\
\hline \multicolumn{4}{|c|}{ TF is Trade Freedom Index converted on I(1) } \\
\hline \multicolumn{4}{|c|}{ Source: Calculated with E-View } \\
\hline
\end{tabular}

\section{Result Analysis for Short Run}

All calculations have been done on individual independent variable at a time.

- If we focus on autoregression of GDP Per Capita (Table 4, 5, 6), it regresses itself on the first lag interval compulsorily. This indicates that the previous year's GDP per capita significantly affects the current amount of GDP per capita in the UAE.

- Value of R-square and adjusted R-square is considerably high in the case of all three independent variables (Table $4,5,6)$ that clearly prove our model's fitness.

- Statistical results of all three independent variables Individually interpret that;

○ Current Financial Freedom (FinF) is negatively related to GDP Per capita, but 't' and 'p' statistics show non-significant values. Lag 1 value of FinF is positively related to GDP per capita and the relationship is very near to be significant. (Table 4).

○ Current Freedom from Corruption (FFC) is positively related to GDP Per capita, but ' $\mathrm{t}$ ' and 'p' statistics show that the relationship is not significant. In contrast, on lag 4, the relationship is significant (Table 5).

- Current Trade Freedom (TF) is positively related to GDP Per capita, but 't' and 'p' statistics show that the relationship is not significant. Whereas, on lag 2 and 3, the relationship is significant (Table 6).

In order to empirically examine long-term relations and short-term dynamic interactions between variables of interest, we use Bounds test on our results (GDP Per Capita, FinF, FFC, TF). We reject the null hypothesis that 'there is no cointegration or long-term relationship between our dependent and independent variable' when F-Statistics are more than upper and lower limits. Bound test is also required along with ARDL in this case.

\section{ARDL Long Run Form and Bound Test}

\section{Coefficient Diagnostics:}

Table 7

\begin{tabular}{|c|c|c|c|c|}
\hline \multicolumn{5}{|c|}{ ARDL Bound test results } \\
\hline \multicolumn{5}{|c|}{ Dependent Variable: Ln(GDP Per Capita PPP\$) } \\
\hline \multicolumn{5}{|c|}{ Independent Variable: Financial Freedom (FinF), Freedom from Corruption (FFC), Trade Freedom (TF) } \\
\hline \multicolumn{5}{|c|}{ Ho: No long-run relationship exists between dependent and independent variables } \\
\hline Variables & F-statistics & Significance level & I (0) & I (1) \\
\hline FinF & 3.149731 & $10 \%$ & 3.02 & 3.51 \\
\hline & & $5 \%$ & 3.62 & 4.16 \\
\hline
\end{tabular}




\begin{tabular}{|l|c|c|c|c|}
\hline \multicolumn{5}{|c|}{ Table 7: Contd., } \\
\hline & & $3 \%$ & 4.18 & 4.79 \\
\hline FFC & $5.562758^{*}$ & $1.00 \%$ & 4.94 & 5.58 \\
\hline TF & $6.536774^{*}$ & $5 \%$ & $3.62^{* *}$ & $4.16^{* *}$ \\
\hline$*$ show value of F-statistics > I(0) or I(1) & $5 \%$ & $3.62^{* *}$ & $4.16^{* *}$ \\
\hline
\end{tabular}

Source: Authors' compilation from E-View results

Table 8

\begin{tabular}{|c|c|c|c|c|}
\hline \multicolumn{5}{|c|}{ Cointegration equation results } \\
\hline \multicolumn{5}{|c|}{ Dependent Variable: Ln(GDP Per Capita PPP\$) } \\
\hline \multicolumn{5}{|c|}{ Independent Variable: Financial Freedom (FinF), Freedom from Corruption (FFC), Trade Freedom (TF) } \\
\hline Variables & Co-efficient & Standard Error & t-statistics & Prob. \\
\hline FinF & 0.007901 & 0.008512 & 0.928198 & 0.3752 \\
\hline FFC & 0.018614 & 0.006438 & $2.89143 * *$ & $0.0135^{*}$ \\
\hline TF & -0.357138 & 0.296788 & -1.203344 & 0.2566 \\
\hline \multicolumn{5}{|c|}{ * show significant value of Prob. } \\
\hline \multicolumn{5}{|c|}{$* *$ show significant value of T-statistics } \\
\hline \multicolumn{5}{|c|}{ Source: Authors' compilation from E-View results } \\
\hline
\end{tabular}

\section{Result Analysis for Bound Test}

As per the extracted F-statistics results of Table 7, Ho is rejected in case of FFC and TF. The relationship between per capita GDP and these variables exists in the long term. However, in case of FinF, the value of F-statistics on all levels of significance lies between or below the upper and lower limits. It is clear that in the long run, Financial Freedom (FinF) is not an influential variable to determine GDP per capita, and therefore in its case, Bound test is not needful.

We can also derive a few results from the cointegration equation (Table 8).

- In case of FinF, the cointegration equation is positive with a coefficient estimate of 0.007901. This implies that the rate of change to long-term balance is $0.7 \%$, which is very low. This means that the device corrects its previous disequilibrium phase at a rate of 0.7 percent within one period of time. Insignificant ' $t$ ' and ' $p$ ' values are also supporting the results of Table 7 in Table 8 that there is no long-term correlation between financial independence and per capita GDP.

- The cointegration equation is positive with a coefficient estimate of 0.018614 in case of FFC. Here the rate of change towards long-run balance is $1.86 \%$, which is much better than FinF. Since T-statistic values and 'p' values are not insignificant, we can conclude that there is a relationship between GDP per capita and freedom from corruption, particularly among high earning countries.

- In case of TF, the cointegration equation is negative with a coefficient estimate of -0.357138 . Here, the change rate to long-term balance is $35.7 \%$, which is quite a good number. T-statistics and ' $p$ ' values are not significant in that there is no long-term relationship between GDP per capita and trade freedom.

\section{Residual Diagnostics:}

Ho: Residuals are not normal

Based on Jarque-Bera, the test residuals are normal as the value of probability is greater than the significant value 
(Table 9).

Table 9

\begin{tabular}{|l|l|l|}
\hline \multicolumn{3}{|l|}{ Based on Jarque-Bera } \\
\hline Variables & Probability & \multicolumn{1}{c|}{ Ho Results } \\
\hline FinF & $0.1756^{*}$ & Rejected \\
\hline FFC & $0.7190^{*}$ & Rejected \\
\hline TF & $0.9351^{*}$ & Rejected \\
\hline$*$ show the significant value of Prob.(if $\mathrm{p}>0.05$, Ho is rejected) \\
\hline \multicolumn{2}{|l|}{ Source: Authors' compilation from E-View results } \\
\hline
\end{tabular}

\section{Breusch-Godfrey Serial Correlation LM Test}

Ho: Variables are not free from serial correlation

This test proves that the residual obtained from the ARDL model is free from serial correlation

Table 10

\begin{tabular}{|l|c|c|l|}
\hline \multicolumn{4}{|l|}{ Breusch-Godfrey Serial Correlation LM Test } \\
\hline Variables & Observed R-Square & Probability & Ho results \\
\hline FinF & 9.2645 & 0.0097 & Accepted \\
\hline FFC & 0.009956 & $0.995^{*}$ & Rejected \\
\hline TF & 3.67733 & $0.159^{*}$ & Rejected \\
\hline * show the significant value of Prob. (if p > 0.05, Ho is rejected) \\
\hline \multicolumn{4}{|l}{ Source: Authors' compilation from E-View results } \\
\hline
\end{tabular}

\section{Heteroscedasticity Test}

Ho: Residuals are not free from heteroscedasticity.

\section{Table 11}

\begin{tabular}{|c|c|c|c|}
\hline \multirow{2}{*}{\multicolumn{4}{|c|}{$\begin{array}{l}\text { Breusch-Pagan-Gogfrey shows that the residues } \\
\text { ARDL model are free from heteroscedasticity. } \\
\text { Breusch-Pagan-Gogfrey Heteroscedasticity Test }\end{array}$}} \\
\hline & & & \\
\hline Variables & Observed R-Square & Probability & Ho Results \\
\hline FinF & 9.739719 & $0.2838^{*}$ & Rejected \\
\hline FFC & 2.518773 & $0.8664 *$ & Rejected \\
\hline TF & 6.588912 & $0.5816^{*}$ & Rejected \\
\hline
\end{tabular}

\section{Stability Diagnostics (CUSUM and CUSUMSQ test):}

In addition, based on the recursive residuals, we used CUSUM and CUSUM square tests to maintain the reliability of the approximate parameters of the long-run relationship of our results developed by Brown et al. . (Brown: Techniques for Testing the Constancy of Regression... - Google Scholar, n.d.)

In case of Financial Freedom, plots of CUSUM and CUSUM squares stayed between the crucial limits of 5\%, proving the stability of the parameters. In case of Freedom from corruption, CUSUMSQ is slightly deviating, though CUSUM is within the limit. In case of Trade freedom, little deviation can be noticed in both. 


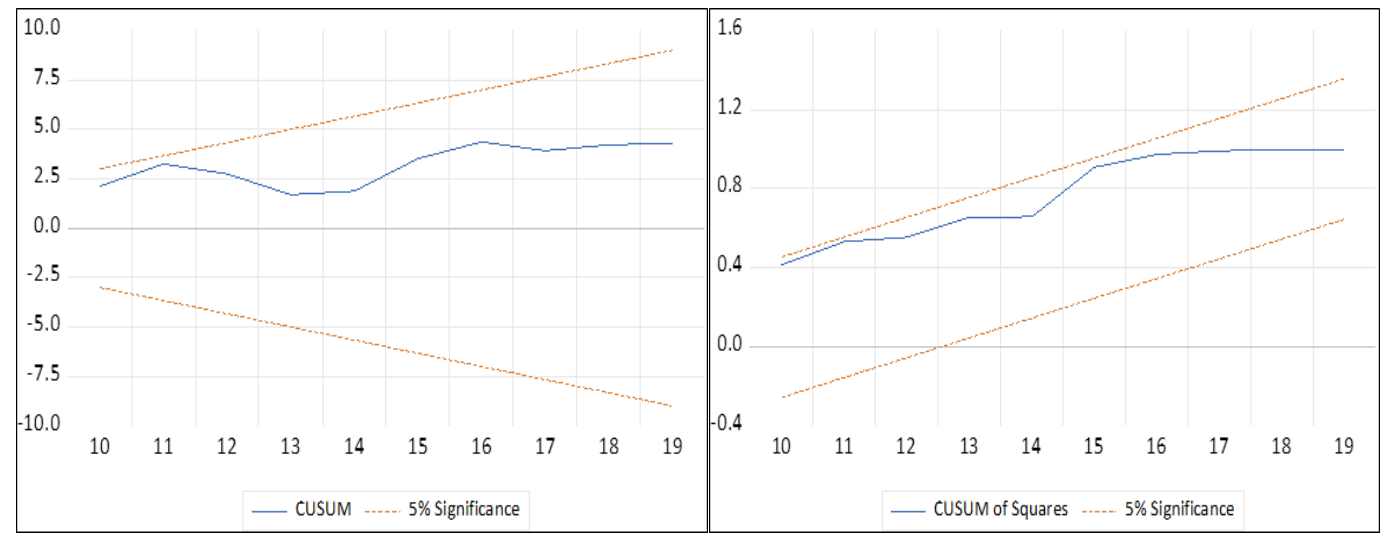

Figure 1: Plots of CUSUM and CUSUM squares when Financial Freedom is the explanatory variable

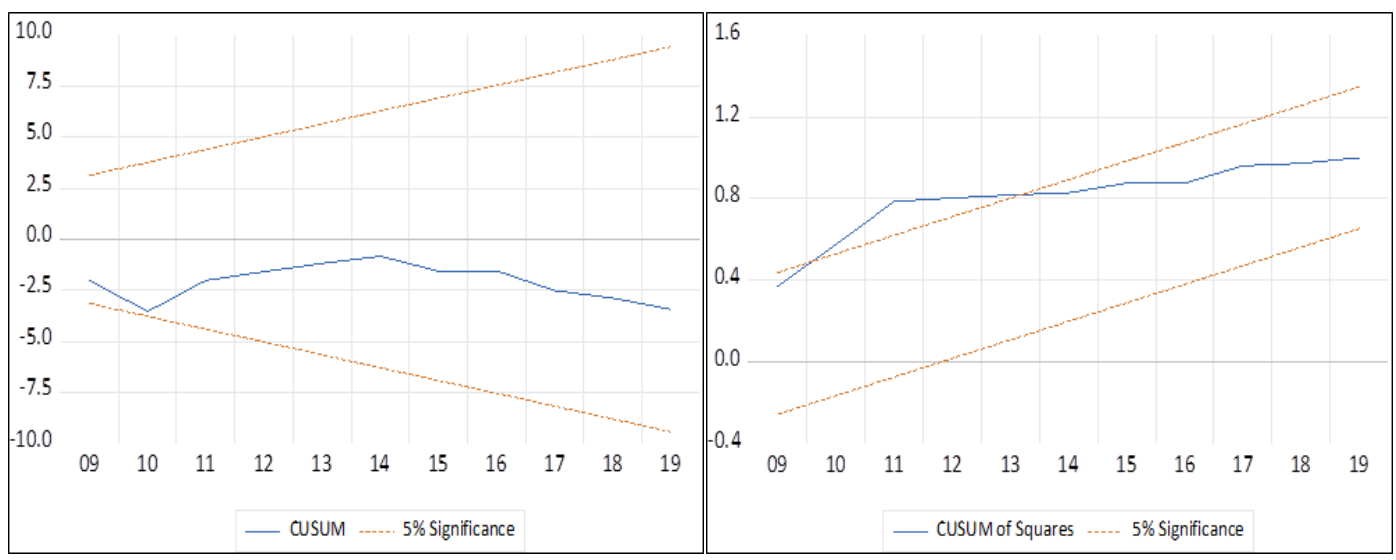

Figure 2: Plots of CUSUM and CUSUM Squares when Freedom from Corruption is the Explanatory Variable

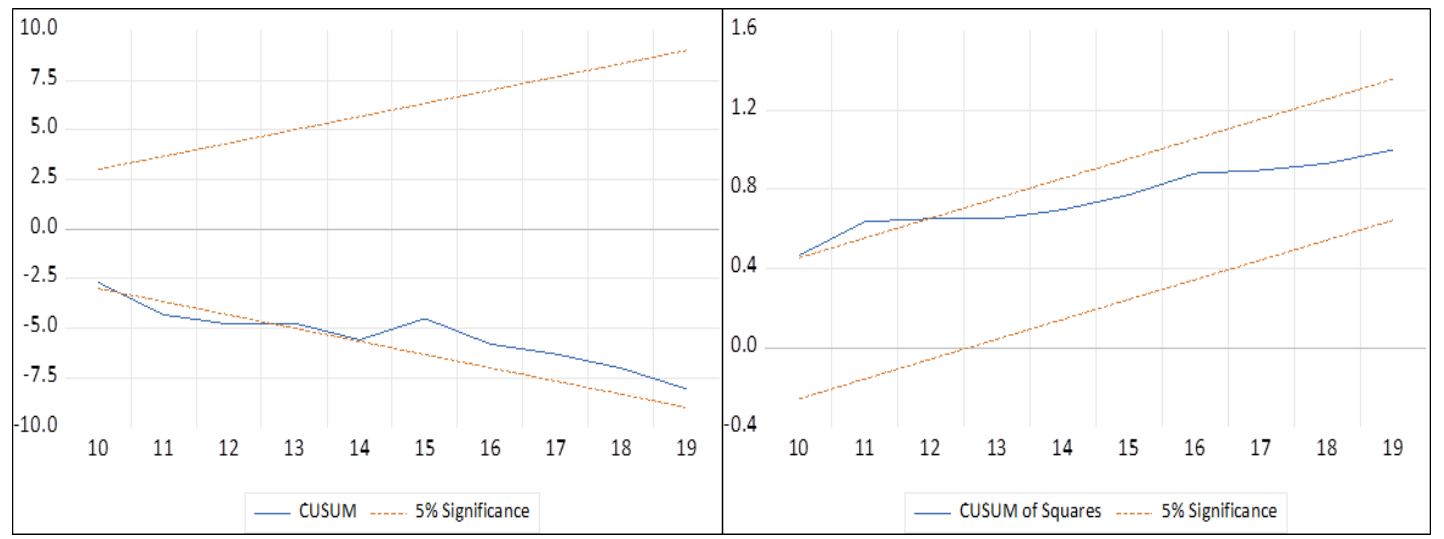

Figure 3: Plots of CUSUM and CUSUM Squares when Trade Freedom is the explanatory Variable

\section{Ramsey Test}

Ho: Model is not well specified

It is used to check an appropriate functional form. 
Table 11

\begin{tabular}{|l|l|l|l|}
\hline \multicolumn{4}{|l|}{ Ramsey RESET Test } \\
\hline Variables & F-Statistics & Probability & Ho results \\
\hline FinF & 0.534467 & $0.4833^{*}$ & Rejected \\
\hline FFC & 3.238071 & $0.0994^{*}$ & Rejected \\
\hline TF & 1.005984 & $0.3421^{*}$ & Rejected \\
\hline * show significant value of Prob. (if p > 0.05, Ho is rejected) \\
\hline \multicolumn{4}{|l|}{ Source: Authors' compilation from E-View results } \\
\hline
\end{tabular}

\section{CONCLUSION AND RECOMMENDATIONS}

We investigated the role of economic freedom in the economic growth and development of UAE using the Bound Testing method. Three determinants of Economic freedom (Financial Freedom (FinF), Freedom from Corruption (FFC), Trade Freedom (TF) out of all eight determinants, are found as significant regressors based on descriptive statistics and therefore focused explicitly in our study. Auto-Regressive Distributed Lag (ARDL) model's empirical results indicated a short-term relationship between GDP per capita PPP\$ and FinF, FFC, and TF determinants. It also proved that the previous year's GDP per capita had a major effect on the current year's GDP per capita of UAE. The long-term ARDL and Bound test also reflected the long-term association between independent and dependent variables.

Although the above study has provided interesting insights, it should be noted that the development of rest of the five leftover economic freedom determinants may contribute to accelerate economic growth. A successful extension of this research would be to consider the lagging of these determinants and the necessary policy measures that can be used and applied to activate them. Because of the heterogeneous nature of economic systems, institutional quality, financial markets, and so on, the effect of economic freedom can differ across countries. However, in order to optimize the economic deepening that needs to be done to ensure that we can obtain the greatest possible value to the economy through this parameter, we believe that our results are of potential interest to policymakers.

\section{ACKNOWLEDGEMENT}

In the course of our work, we have been benefited greatly from discussions with our colleagues. It's our pleasure to acknowledge our indebtedness to our college authorities and Jazan University as well for becoming a good infrastructure provider. We must express our deep sense of gratitude to each person who had been proved to be a true advisor. We recall assistance and encouragement of many people for providing us valuable suggestions and moral support.

\section{REFERENCES}

1. Al-Gasaymeh, A. (2020). Economic freedom, country risk and cost efficiency in Jordan and the GCC countries. Global Business Review, 21(1), 1-17.

2. Altaee, H., \& Al-Jafari, M. K. (2018). Trade Openness and Economic Growth in the GCC Countries: A Panel Data Analysis Approach. International Journal of Business and Economic Sciences Applied Research.

3. Beheshtitabar, E., \& Irgaliyev, A. (2008). The Impact of Economic Freedom on FDI Inflows to Developing Countries: The Case of the Middle East.

4. Brown: Techniques for testing the constancy of regression... - Google Scholar. (n.d.). Retrieved December 9, 2020, from https://scholar.google.com/scholar_lookup?title=Techniques\%20for\%20testing\%20the\%20Constancy\%20of\%20regression\% 20relationships\%20over\%20time\&journal $=R \% 20$ Stat $\% 20$ Soc \& volume $=37 \&$ issue $=2$ \&pages $=149$ - 
$192 \&$ publication_year $=1975 \&$ author $=$ Brown\%2CRL\&author $=$ Durbin\%2CJ\&author $=$ Evans\%2CJM

5. Caetano, J., \& Caleiro, A. (2009). Economic Freedom and Foreign Direct Investment-How different are the MENA countries from the EU? Documento de Trabalho.

6. Country Rankings: World \& Global Economy Rankings on Economic Freedom. (n.d.). Retrieved November 4, 2020, from http://www.heritage.org/index/ranking

7. Eldomiaty, T. I., Al Qassemi, T. B. F., Mabrouk, A. F., \& Abdelghany, L. S. (2016). Institutional quality, economic freedom and stock market volatility in the MENA region. Macroeconomics and Finance in Emerging Market Economies, 9(3), 262283.

8. Facchini, F. (2013). Economic Freedom in Muslim Countries: An Explanation Using the Theory of Institutional Path Dependency. European Journal of Law and Economics, 36(1), 139-167.

9. Goldsmith, A. A. (1997). Economic rights and government in developing countries: Cross-national evidence on growth and development. Studies in Comparative International Development, 32(2), 29-44.

10. Hussain, M., \& Haque, M. (2016). Impact of Economic Freedom on the Growth Rate: A Panel Data Analysis. Economies, 4(4), 5. https://doi.org/10.3390/economies4020005

11. Hussein, M. A. (2009). Impacts of foreign direct investment on economic growth in the Gulf Cooperation Council (GCC) Countries. International Review of Business Research Papers, 5(3), 362-376.

12. Johansen, S., \& Juselius, K. (1990). Maximum likelihood estimation and inference on cointegration-With appucations to the demand for money. Oxford Bulletin of Economics and Statistics, 52(2), 169-210.

13. Kinnunen, J. (2018). Islamic Countries Clustered and Analysed by Economic and Political Freedoms and GDP. Proceedings of the 6th International Islam \& Liberty Conference: Building an Islamic Case for Open Markets, 19.

14. Laura Asandului1, Andreea Iacobuta2, Cristina Cautisanu3. (2015). Modelling Economic Growth Based on Economic Freedom and Social Progress. European Journal of Sustainable Development, 5(3). https://doi.org/10.14207/ejsd.2016.v5n3p229

15. Laurenceson, J., \& Chai, J. C. (2003). Financial reform and economic development in China. Edward Elgar Publishing.

16. Masoud, N., \& Hardaker, G. (2012). The impact of financial development on economic growth. Studies in Economics and Finance.

17. Mimoun, M. B., \& Essaggay, A. (2018). Economic Freedom, TFP and Growth: Comparative Analysis of GCC and East Asian Newly Industrialized Economies (NIEs). Academic Journal of Business, 4(1).

18. Narayan, P. K. (2005). The saving and investment nexus for China: Evidence from cointegration tests. Applied Economics, 37(17), 1979-1990.

19. Pesaran, M. H. (1997). The role of economic theory in modelling the long run. The Economic Journal, 107(440), $178-191$.

20. Pesaran, M. H., Shin, Y., \& Smith, R. P. (1999). Pooled mean group estimation of dynamic heterogeneous panels. Journal of the American Statistical Association, 94(446), 621-634.

21. Smimou, K., \& Karabegovic, A. (2010). On the relationship between economic freedom and equity returns in the emerging markets: Evidence from the Middle East and North Africa (MENA) stock markets. Emerging Markets Review, 11(2), 119-151.

22. United Arab Emirates Economic freedom, overall index-Data, chart. (n.d.). TheGlobalEconomy.Com. Retrieved November 28, 2020, from https://www.theglobaleconomy.com/United-Arab-Emirates/economic_freedom/ 


\section{AUTHOR PROFILE}

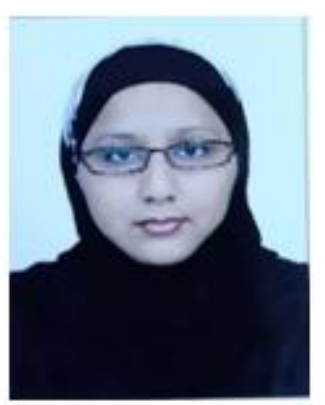

Dr Ruby Khan is purely an academician. Currently she is working as an Assistant Professor in Department of Finance and Banking, College of Business Administration, Jazan University, Jazan, KSA. She obtained her Ph.D. degree from Department of Economics, Aligarh Muslim University, Aligarh, India.

Her principle research interests lie in the field of development and growth of Infrastructure Sector (physical, social, financial) of any country and further its impact on the economic growth of that country. Her writing work is mostly on Regional Disparities in India, Need for Infrastructure Reforms in India, Development of Social Infrastructure and Economic Growth of any Country etc. Her publications are under topics such as 'Performance of the Indian Agriculture under WTO Regime', 'Role of Infrastructure in Saudi Arabian Economy', 'Impact of Bank Lending on Economic Development in KSA', 'Impact of Geographical Expansion on Economic Development: Case Study of Jazan City' and 'Remittances; Development Mantra or a Dutch Disease for a Developing Country'.

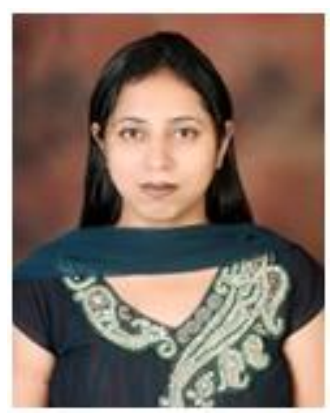

Dr Kavita Panjwani is Assistant Professor in Finance and Banking Department, College of Business Administration (Girls), Jazan University, Jazan (K.S.A). She has completed her Ph.D. on the topic of "An Analytical Study of Investment Practices and Performance of Mutual Funds in India" and M.Phil on the topic of "An Analytical Study of Stock Market Anomalies".

She has presented and published many research papers in various national and international conferences/seminars and referred Journals. She has published two books on the title "Business accounting" and "Managerial economics". Recently, she is also member of editorial board as panel of reviewers in "Asian Journal of Finance and Accounting (United States) and Journal of Business and Retail Management Research (JBRMR), SDIMT Management Review (India) "International Journal of Financial market and Corporate Finance (IJFMCF) BOHR Centreville, USA. During her academic assignments, she has developed many case studies, business games and role-playing exercises. She has numerous research works to her credit. She has acted as head of MBA and BBA programme and guided many research scholars in the area of finance in Ganpati institute of management and technology (Bilaspur), Kurukshetra university India as well as 
UAE Through Bounds Testing Approach

College of business administration, Jazan university Jazan, Saudi Arabia.

The areas of interest include Financial management, Portfolio and Mutual funds, Security analysis, Personal financial planning, Wealth management, Business Accounts, Income tax law, Strategic financial Management and Statistics. At last philosophy of her life "Winner never quit and quitters never win".

\section{APPENDICES I}

UAE: GDP per capita, PPP (measure: U.S. dollars), and Economic freedom indices (measure: index points)

\begin{tabular}{|c|c|c|c|c|c|c|c|c|c|c|c|}
\hline Years & $\begin{array}{l}\text { Property } \\
\text { rights } \\
\text { (PR) }\end{array}$ & $\begin{array}{l}\text { Freedom } \\
\text { from } \\
\text { corruption } \\
\text { (FFC) } \\
\end{array}$ & $\begin{array}{c}\text { Freedom } \\
\text { of Fiscal } \\
\text { (FF) }\end{array}$ & $\begin{array}{l}\text { Freedom of } \\
\text { Business } \\
\text { (FB) }\end{array}$ & $\begin{array}{c}\text { Freedom of } \\
\text { Monetary } \\
\text { (FM) }\end{array}$ & $\begin{array}{c}\text { Freedom } \\
\text { of Trade } \\
\text { (FT) }\end{array}$ & $\begin{array}{l}\text { Freedom of } \\
\text { Investment } \\
\text { (FI) }\end{array}$ & $\begin{array}{c}\text { Freedom } \\
\text { of Finance } \\
\text { (FFin) }\end{array}$ & $\begin{array}{c}\text { Overall } \\
\text { EFI }\end{array}$ & $\begin{array}{c}\text { GDP Per } \\
\text { Capita PPP \$ } \\
\text { (measure: U.S. } \\
\text { dollars) }\end{array}$ & $\begin{array}{c}\text { Ln(GDP } \\
\text { Per } \\
\text { Capita) }\end{array}$ \\
\hline 1996 & 90 & 90 & 100 & 85 & 75.2 & 77 & 30 & 50 & 72 & 102211.44 & 11.5348 \\
\hline 1997 & 90 & 90 & 100 & 85 & 76.1 & 77 & 30 & 50 & 72 & 105108.95 & 11.56275 \\
\hline 1998 & 90 & 90 & 100 & 85 & 78 & 76 & 30 & 50 & 72 & 100100.44 & 11.51393 \\
\hline 1999 & 90 & 90 & 100 & 85 & 78.9 & 77 & 30 & 50 & 72 & 97698.38 & 11.48964 \\
\hline 2000 & 90 & 90 & 100 & 85 & 80.4 & 77 & 30 & 50 & 74 & 102494.88 & 11.53757 \\
\hline 2001 & 90 & 90 & 100 & 85 & 80.7 & 77 & 50 & 50 & 75 & 98621.63 & 11.49905 \\
\hline 2002 & 70 & 90 & 100 & 85 & 81.9 & 77 & 50 & 50 & 74 & 95908.92 & 11.47115 \\
\hline 2003 & 70 & 90 & 100 & 70 & 85.2 & 77 & 50 & 50 & 73 & 97795 & 11.49063 \\
\hline 2004 & 70 & 70 & 100 & 70 & 79.5 & 77 & 50 & 30 & 67 & 97758.02 & 11.49025 \\
\hline 2005 & 50 & 52 & 100 & 70 & 79 & 77 & 50 & 30 & 65 & 90894.84 & 11.41746 \\
\hline 2006 & 50 & 61 & 99 & 49 & 76.8 & 75 & 30 & 30 & 62 & 86425.87 & 11.36704 \\
\hline 2007 & 40 & 62 & 100 & 49 & 73.6 & 75 & 30 & 40 & 63 & 76620.41 & 11.24662 \\
\hline 2008 & 40 & 62 & 100 & 48 & 70.9 & 80 & 30 & 40 & 63 & 68795.41 & 11.13889 \\
\hline 2009 & 40 & 57 & 100 & 57 & 69.8 & 81 & 30 & 50 & 65 & 58374.59 & 10.97464 \\
\hline 2010 & 50 & 59 & 100 & 67 & 68.8 & 83 & 35 & 50 & 67 & 54921.84 & 10.91367 \\
\hline 2011 & 50 & 65 & 100 & 67 & 76.5 & 83 & 35 & 50 & 68 & 56123.48 & 10.93531 \\
\hline 2012 & 55 & 63 & 100 & 68 & 80.9 & 83 & 35 & 50 & 69 & 57390.71 & 10.95764 \\
\hline 2013 & 55 & 68 & 100 & 74 & 83.9 & 83 & 35 & 50 & 71 & 59921.73 & 11.00079 \\
\hline 2014 & 55 & 66 & 100 & 74 & 84.6 & 83 & 35 & 50 & 71 & 62379.66 & 11.04099 \\
\hline 2015 & 55 & 69 & 100 & 75 & 83.8 & 82 & 40 & 50 & 72 & 65218.79 & 11.0855 \\
\hline 2016 & 55 & 70 & 95 & 80 & 81.3 & 83 & 45 & 60 & 73 & 66510.87 & 11.10512 \\
\hline 2017 & 77 & 74 & 96 & 81 & 78.4 & 84 & 40 & 60 & 77 & 67183.63 & 11.11518 \\
\hline 2018 & 76 & 77 & 98 & 80 & 80.2 & 84 & 40 & 60 & 78 & 66968.27 & 11.11197 \\
\hline 2019 & 82 & 79 & 99 & 80 & 80.9 & 84 & 40 & 60 & 78 & 67119.13 & 11.11422 \\
\hline 2020 & 80 & 65 & 99 & 79 & 79.6 & 80 & 40 & 60 & 76 & NA & \#VALUE! \\
\hline
\end{tabular}


